\title{
Test of hypotheses about herbivory and chemical defences of Qualea parviflora (Vochysiaceae) in Brazilian Cerrado ${ }^{1}$
}

\author{
SILMARY J. GONÇALVES-ALVIM ${ }^{2,3,4}$, TATE C. LANA ${ }^{3}$, BERNARDO D. RANIERI $^{3}$ and \\ GERALDO WILSON FERNANDES ${ }^{3}$
}

(received: August 12, 2009; accepted: May 19, 2011)

\begin{abstract}
Test of hypotheses about herbivory and chemical defences of Qualea parviflora (Vochysiaceae) in Brazilian Cerrado). Qualea parviflora Mart. (Vochysiaceae), a widely distributed tree found in different habitats in Brazilian Cerrado (savanna), provides resources for a great variety of insects. In this study, we tested two hypotheses about plant investment in anti-herbivore defences along a fertility gradient in Cerrado: the carbon/nitrogen balance (CNBH) and resource availability (RAH). We also investigated how the pattern of herbivory varies through the year and among three types of vegetation in Brazilian Cerrado - campo sujo, cerrado sensu strictu and cerradão. Sampling was conducted in three types of vegetation and in rainy (January and November) and dry months (April and July). Damage on 20 completely expanded leaves, leaf nutrients, sclerophlylly, total phenols and tannins were recorded for each plant $(n=30)$. When leaves were young, less sclerophyllous, and with higher concentration of nutrients and tannins, damage by herbivores was about $7 \%$ in cerrado sensu stricto and $3 \%$ in campo sujo. Mature leaves did not show any significant difference on herbivory among habitats, that varied from 6 to $9 \%$. Nutrient availability to plants is an important factor determining production of secondary metabolites in $Q$. parviflora, corroborating the $\mathrm{CNBH}$. The absence of correlation between damaged leaf area and tannin concentration did not corroborate the RAH, suggesting that tannin production is not strongly influenced by herbivores on Q. parviflora.
\end{abstract}

Key words - Brazilian savanna, insect-plant interaction, leaf damage, plant defences

RESUMO - (Teste de hipóteses sobre herbivoria e defesas químicas de Qualea parviflora (Vochysiaceae) no Cerrado brasileiro). Qualea parviflora Mart. (Vochysiaceae), uma árvore amplamente distribuída em diferentes habitats no Cerrado brasileiro, fornece recursos para uma grande variedade de insetos. Neste estudo, foram testadas duas hipóteses sobre o investimento em defesas contra herbívoros ao longo de um gradiente de fertilidade no Cerrado: as hipóteses do balanço carbono/nutriente (CNBH) e da disponibilidade de recursos (RAH). Foi também investigado como os padrões de herbivoria variam ao longo do ano e entre as diferentes fisionomias do Cerrado - campo sujo, cerrado sensu stricto e cerradão. As amostragens foram realizadas em três tipos de fisionomias nos períodos chuvoso (janeiro e novembro) e seco (abril e julho). Danos em 20 folhas completamente expandidas, teores de nutrientes foliares, esclerofilia, fenóis totais e taninos foram obtidos para cada planta $(n=30)$. Quando as folhas estavam jovens, menos esclerófilas e com maior concentração de nutrientes e taninos, danos por herbívoros foram cerca de 7\% no cerrado sensu stricto e 3\% no campo sujo. Folhas maduras não apresentaram nenhuma diferença significativa na herbivoria entre os diferentes habitats, que variou de 6 a $9 \%$. A disponibilidade de nutrientes para a planta é um fator que determina a produção de compostos secundários em Q. parviflora, corroborando a CNBH. Além disso, a ausência de correlação entre a área foliar danificada e o teor de taninos não corrobora a RAH, sugerindo que a produção de taninos não seja influenciada fortemente pela pressão de herbívoros em Q. parviflora.

Palavras-chave - dano foliar, defesas de plantas, interação inseto-planta, savana brasileira

\section{Introduction}

Water, chemical and mechanical defences vary not only intraspecifically, but also with plant developmental

1. Part of the first author`s PhD thesis, Programa de Pós-Graduação em Ecologia, Manejo e Conservação da Vida Silvestre, Universidade Federal de Minas Gerais, Belo Horizonte, MG, Brazil.

2. Conselho Nacional de Desenvolvimento Científico e TecnológicoCNPq, Coordenação-Geral do Programa de Pesquisa em Ciências da Terra e do Meio Ambiente - CGCTM, SHIS QI 1 Conjunto B, Bloco A, Edifício Santos Dumont, Lago Sul, 71605-001 Brasília, DF, Brazil.

3. Universidade Federal de Minas Gerais, Laboratório de Ecologia Evolutiva e Biodiversidade/DBG/ICB, Caixa Postal 486, 30161970 Belo Horizonte, MG, Brazil.

4. Corresponding author: silmaryalvim@uol.com.br stage (Ernest 1989). Also, seasonal changes in the nutritional quality of the leaves can strongly influence life history, composition, and abundance patterns of insect herbivores (Schultz et al. 1982, Cornelissen \& Fernandes 2001). In tropical seasonal vegetation the timing of folivorous damage is particularly important given the strong seasonality within a year, and the considerable climatic variation year to year (Filip et al. 1995). Insect populations and leaf damage are often higher during the rainy season (Janzen \& Schoner 1968, Janzen 1973, Wolda 1978, Filip et al. 1995). However, temporal variation in leaf damage within the rainy season can also be observed and it may be due to the abundance of insect defoliators, whose population peaks 
tend to occur during the first half of the rainy season (Janzen 1981).

Chemical plant defences are usually products of secondary metabolism in plant tissues and are known as allelochemicals or secondary metabolites (Whittaker $\&$ Feeny 1971). Among these compounds, phenols are characterized by an aromatic ring with one or more hydroxyl groups. The tannins are polyphenols with high molecular weight and generally found in soluble forms in different parts of vascular plants (Schoonhoven et al. 1998). The two larger groups of tannins are the condensed, more common among all plants, and the hydrolysable, which are restricted to dicotyledonous plants (Bernays et al. 1989).

Phenolic compounds have a role in a great variety of plant activities and their defensive role can be the result of selective pressure of the environment, such as competition, nutritional deficiency, drought, ultraviolet radiation, and herbivory (Bernays et al. 1989, Hagerman \& Butler 1991, Schoonhoven et al. 1998). Thus, chemical defences can vary among sites when resources differ in availability and also affect intraspecific herbivory (Ernest 1989). Several hypotheses have been proposed to explain this pattern. For example, when nitrogen limits plant growth, the carbon/nutrient balance hypothesis (CNBH) (Bryant et al. 1983) predicts that carbohydrates will be accumulated in plant tissues and used for tissue differentiation products, increasing the synthesis of carbon-based secondary metabolites. In addition, Allain et al. (1998) argued that higher photosynthetic rates of plants associated with low nutrient content in soils of Cerrado (Savanna) results in an excess of carbon that could be allocated in many pathways such as for fibre and tannins.

The resource availability hypothesis (RAH) proposes that quantitative chemical defences based on carbon (such as tannins and terpenes) should be favoured in nutrient-poor environments, where slowgrowing plants are expected to allocate more resources to defence because tissue loss is more expensive (Coley et al. 1985). In addition, Coley and colleagues argued that the growth of plants in habitats with excess light and nutrients would be associated with production of simple tissues and with lower concentration of phenolic compounds, where herbivore damage is negligible. Thus, RAH predicts that the selective pressure of herbivory could affect the production of secondary compounds (Ribeiro \& Fernandes 2000) while the CNBH does not explicitly assume that the chemical structure or quantity of secondary metabolites produced reflects selection pressures exerted by herbivores (Tuomi et al. 1988).
Environmental factors affecting the plant defences and its response to herbivory are extremely variable, and still poorly understood in Cerrado. We examined these effects on Qualea parviflora Mart. (Vochysiaceae), a deciduous species that accumulates aluminium (with leaf Al concentration above 10,000 $\mathrm{mkg}^{-1}$; Haridasan 1982), remaining leafless for one month at the end of dry season (Morais et al. 1995, Oliveira \& Gibbs 2000). This species is an ornamental tree, and resins produced by its bark are used in Brazil to produce pigments (Barroso 1991, Lorenzi 2000). In the Cerrado biome, Q. parviflora is commonly observed in the physiognomies of campo sujo, cerrado sensu stricto and cerradão and is intensively attacked by folivorous insects of Coleoptera, Hemiptera, Hymenoptera, Blattodea, and Orthoptera groups (see Gonçalves-Alvim et al. 2006).

The structure and physiognomies of Cerrado reflect climatic and other environmental variables (Furley 1999) but, in general, the more fertile mesotrophic soils tend to support cerradão vegetation and show higher $\mathrm{pH}$ and relatively higher phosphorous and nitrogen content than dystrophic soils which frequently support campo sujo vegetation (Lopes \& Cox 1977, Goodland \& Ferri 1979, Felippe \& Dale 1990). In addition, Gonçalves-Alvim et al. (2006) found higher concentration of silicium, nitrates and organic matter in soils of cerradão, and lower in campo sujo. Thus, this system is ideal to test hypotheses about plant investment in anti-herbivore defences along a fertility gradient in Cerrado: cerradão $>$ cerrado sensu stricto $>$ campo sujo. We also investigated how the pattern of herbivory varies throughout the year and among different types of Cerrado vegetation in southeastern Brazil.

\section{Material and methods}

Area of study - The study was carried in the year 2000 at the Ecological Station of Pirapitinga (ESP) that has an area of approximately 1,000 ha and is located in southeastern Brazil $\left(18^{\circ} 20^{\prime}-18^{\circ} 23^{\prime} \mathrm{S}\right.$ and $\left.45^{\circ} 17^{\prime}-45^{\circ} 20^{\prime} \mathrm{W}\right)$ at an altitude of 590-630 m above sea level (Azevedo et al. 1987, GonçalvesAlvim \& Fernandes 2001). Three vegetation types of Brazilian Cerrado (Savanna) were studied: campo sujo, a widely scattered tree and shrub savanna with a canopy cover of less than $2 \%$; cerrado sensu stricto, a savanna woodland with total woody cover of about $20 \%$; and cerradão, a xeromorphic forest with a fairly continuous tree stratum and canopy cover which ranges from 15 to 85\% (Eiten 1972, Felippe \& Dale 1990). The climate is wet and hot tropical (Aw type of Köppen 1931), with a long dry season (up to 4 mo.), mean annual temperature from $20^{\circ}$ to $26^{\circ} \mathrm{C}$, and mean annual precipitation exceeding $1,600 \mathrm{~mm}$ (Gonçalves-Alvim \& Fernandes 2001). 
Samplings and chemical analyses of leaves - Leaves were sampled in January (middle of rainy season), April (end of rainy season-beginning of the dry season), July (middle of dry season) and November (beginning of the rainy season) in the year 2000. Leaf age was estimated by the time of sampling and leaf traits. Ten plants were randomly selected and sampled in each one of the Cerrado physiognomies in ESP ( $n=30$ trees) at each date. Completely expanded and undamaged leaves were collected for nutrient analyses $(n=20)$, total phenols $(n=10)$, and tannins $(n=3)$. The mean concentration of nitrogen (\%), carbon (\%), aluminium $(\%)$, silicon (\%), total phenols (\%) and tannins (\%) were obtained for each plant at each date. Nitrogen was analyzed by Flow Injection Analysis - FIA (Carlson et al. 1990), and carbon was determined indirectly by the WalkleyBlack method (Walkley-Black 1934). Silica was analyzed colorimetrically (Elliott \& Snyder 1991), and with an atomic absortion spectrophotometer (Meyer \& Keliher 1992). Condensed and hydrolysable tannins were obtained by the method of radial diffusion (Hagerman 1987), in which fresh leaves were used with three replicates for each plant. For total polyphenols, the leaves were previously dried at room temperature, ground, and analyzed using the Folin-Denis method of Swain (1979). Total phenolic assays used tannic acid for standard curves, and are expressed as percentage (dry mass) of tannic acid equivalents (TAE). The analyses were conducted at the Laboratório de Ecologia Evolutiva de Herbívoros Tropicais and the Laboratório de Fisiologia Vegetal of Instituto de Ciências Biológicas at Universidade Federal de Minas Gerais.

We also quantified leaf sclerophylly for each tree, measured indirectly by the most widely used and easy to obtain index, the leaf specific mass - LSM (Witkowisk \& Lamont 1991). The LSM $\left(\mathrm{g} \mathrm{m}^{-2}\right)$ was calculated in 20 fully expanded and non-damaged leaves for each plant. Leaves were drawn and scanned to measure the leaf area, and then were oven-dried at $45{ }^{\circ} \mathrm{C}$ for at least 72 hours and the mass of the dry matter component was determined (for details see Gonçalves-Alvim et al. 2006).

Herbivory damage - For each tree, 10 shoots were randomly collected around the circumference of each plant $(n=300$ shoots). At each sampling month, the total number of leaves and the number of leaves attacked by herbivorous insects were recorded. Herbivory was quantified on two randomly selected completely expanded leaves on each shoot $(n=20$ leaves per plant), which were removed and digitized by a scanner at the laboratory. The total leaf area $\left(\mathrm{cm}^{2}\right)$ and percentage of leaf area damaged were calculated using the computer program Scion-Image (1998). Herbivorous attack was estimated by the mean percentage of leaf area damaged. Only herbivore damage that resulted in lamina loss (leaf removal, chewing, or mining) was included (see Moles \& Westoby 2000).

Statistical analyses - All variables used in statistical analyses were initially submitted to the Ryan-Joiner test for normality and to the Bartlett test for homogeneity of variances $(\alpha=0.05)$. When a variable did not show normalized distribution and parametric statistics was appropriate, arc-sin transformations were used for normalization of data (Zar 1996).

Differences in percentage of leaf area removed, concentration of chemical defences, and leaf nutrients among vegetation types and different leaf ages were tested using analysis of variance (ANOVA) or Kruskal Wallis (to compare independent samples), and Friedman test to compare dependent samples, followed by complementary tests for multiple comparisons (Tukey or Wilcoxon) with the significance level of 0.05 (Zar 1996).

To test the hypotheses about investment in anti-herbivore defences of $Q$. parviflora, correlation and simple linear regression analyses were used to determine the significant relationship between herbivore damage and leaf chemical defences on $Q$. parviflora with the significance level of 0.05 . The matrix of Bonferroni probabilities was used as post hoc test to determine the significant differences after correlation analyses (Zar 1996).

\section{Results}

Herbivory damage - Approximately $76.8 \%$ of the examined leaves $(n=9,820)$ of $Q$. parviflora showed damage by herbivorous insects. The mean percentage of leaf area removed in Q. parviflora was $6.1 \%$, varying from 3.1 to $9.8 \%$. The plants of the cerrado sensu stricto ( $7.6 \pm 0.5 \%$ of leaf area removed) had the highest herbivory, whereas plants in cerradão $(5.0 \pm 0.5 \%)$ and campo sujo $(4.6 \pm 0.4 \%)$ showed the lowest leaf area removal values (ANOVA, $\mathrm{F}_{120,1}=10.7$, $P<0.0001)$.

When leaves were younger, less sclerophyllous, and with higher concentration of nutrients and tannins (Gonçalves-Alvim et al. 2006), damage by herbivores was about $7 \%$ in cerrado sensu stricto and 3\% in campo sujo. Mature leaves did not show any significant difference on herbivory among habitats varying from 6 to $9 \%$ (Friedman $=29.16, P<0.0001)$. As shown in figure 1 for damages throughout the entire growing season.

Tests of hypotheses on Qualea parviflora defences Total phenols and tannins were found in leaves of $Q$. parviflora with mean concentrations that varied from 0.9 to $2.6 \%$, however, there were no significant differences in plant defences and leaf nutrients among the three types of vegetation $(P>0.05)$. Mature leaves showed less tannins than younger leaves, while total phenols were observed in higher concentration in leaves with intermediate ages, during the dry season. 


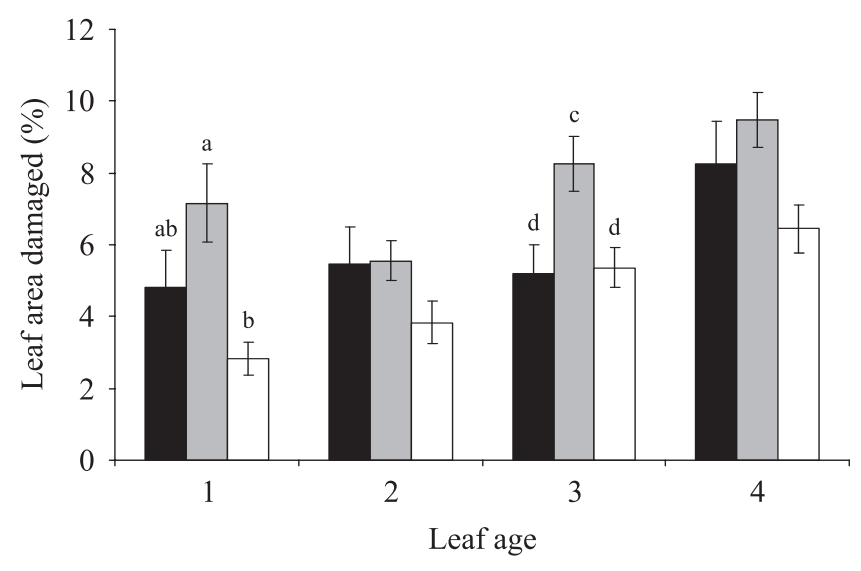

Figure 1. Leaf area damaged ( $\bar{x} \pm \mathrm{SE})$ of Qualea parviflora for each leaf age and physiognomy at Ecological Station of Pirapitinga in year 2000. Different letters for each column indicate statistically significant differences (ANOVA; $\alpha=0.05)$. ( $\square=$ cerradão, $\square=$ cerrado sensu strictu; $\square=$ campo sujo; 1 = young leaves; $2-3$ = intermediary ages; and $4=$ mature leaves).

Tannins were negatively correlated with nitrogen, while significant relationships between aluminium and these secondary compounds were observed in $Q$. parviflora (table 1). Tannins also correlated positively with $\mathrm{C} / \mathrm{N}$ ratio, indicating that most of the carbon could be redirected for the production of these phenolic metabolites. Thus, individuals of $Q$. parviflora with higher $\mathrm{C} / \mathrm{N}$ ratio have leaves richer in tannins (table 1 ), in agreement with the CNBH. In addition, $62 \%$ of the variation observed in tannin concentration was explained by the variation in aluminium concentration of $Q$. parviflora leaves (figure 2A).

There was a negative relationship between herbivore damage and nitrogen and tannin concentration in $Q$. parviflora (table 1). We also observed a tendency of leaf area damaged by herbivores to increase with increasing contents of carbon, aluminum, $\mathrm{C} / \mathrm{N}$ ratio, and total phenols in the leaves, although the latter without significant relationships (table 1). Only the nitrogen
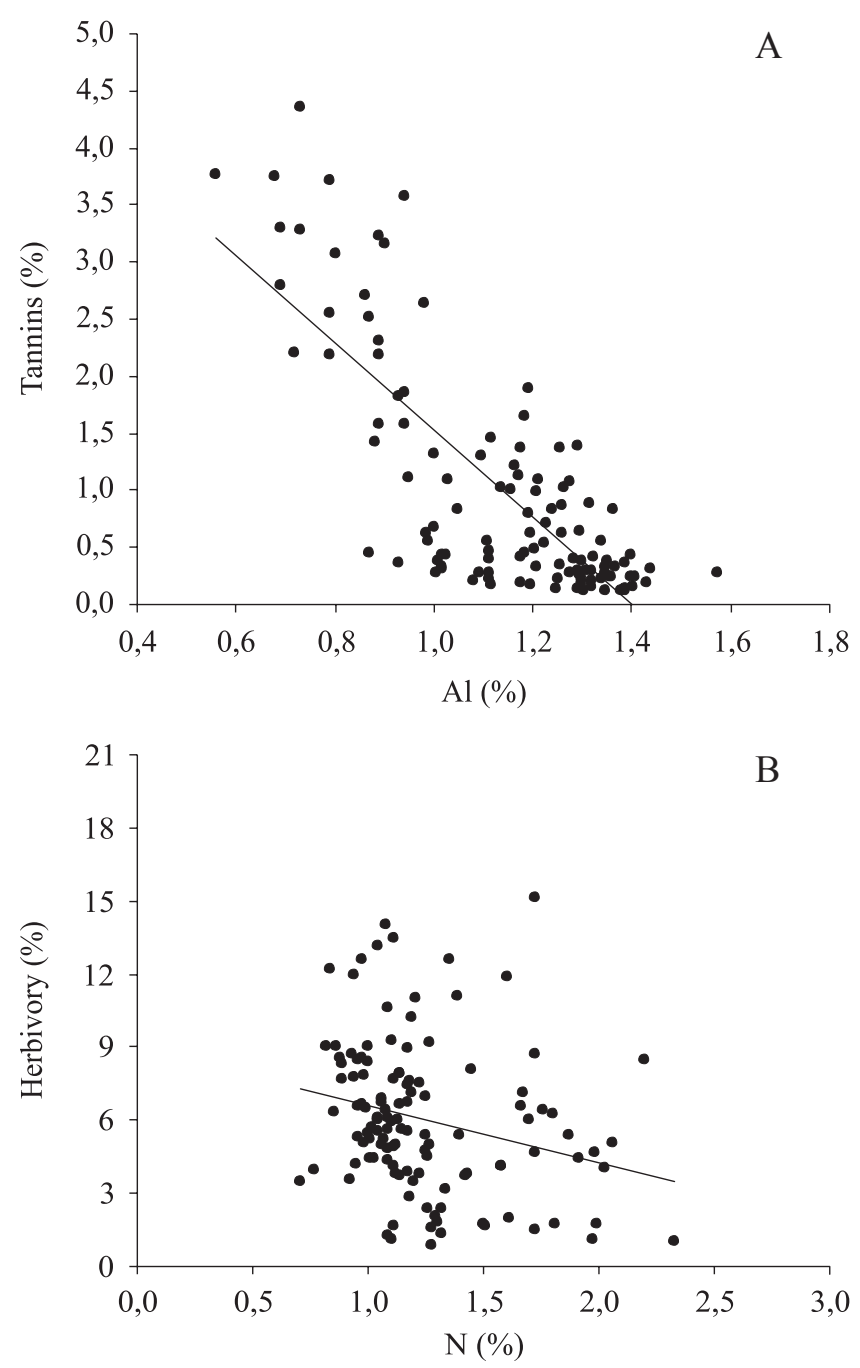

Figure 2. Relationships between A. tannins and aluminium concentration $\left(\mathrm{r}^{2}=0.62 ; \mathrm{y}=-3.83 * \mathrm{Al}+5.35 ; \mathrm{F}_{115,1}=10.35\right.$; $P<0.05$ ); and $\mathrm{B}$. herbivory and nitrogen concentration in Qualea parviflora (Vochysiaceae) leaves $\left(\mathrm{r}^{2}=0.10\right.$; $\left.\mathrm{y}=-2.35 * \mathrm{~N}+8.98, \mathrm{~F}_{118,1}=10.35 ; P<0.05\right)$.

concentration showed a linear significant relationship with herbivore damage $\left(\mathrm{r}^{2}=0.10 ; \mathrm{F}_{118,1}=10.3 ; P<0.05\right.$; figure $2 \mathrm{~B}$ ), not in agreement with the RAH.

Table 1 - Matrix of Spearman correlation index of herbivory, phenols and nutritional status of Q. parviflora averaged for all leaf ages ( $n=30$ trees; in bold significant relationships from matrix of Bonferroni probabilities; $\alpha=0.05)$.

\begin{tabular}{lccccccc}
\hline & Herbivory & Tannins & Total phenols & $\mathrm{C}$ & $\mathrm{N}$ & $\mathrm{C} / \mathrm{N}$ & $\mathrm{Al}$ \\
\hline Tannins & -0.23 & - & - & - & - & - & - \\
Total phenols & 0.08 & -0.08 & - & - & - & - & - \\
$\mathrm{C}$ & 0.03 & -0.33 & 0.37 & - & - & - & - \\
$\mathrm{N}$ & -0.32 & $\mathbf{- 0 . 5 6}$ & -0.24 & $\mathbf{- 0 . 5 0}$ & - & - & - \\
$\mathrm{C} / \mathrm{N}$ & 0.31 & $\mathbf{0 . 5 6}$ & 0.28 & $\mathbf{0 . 6 0}$ & $\mathbf{- 0 . 9 8}$ & - & - \\
$\mathrm{Al}$ & 0.25 & $\mathbf{- 0 . 7 0}$ & 0.14 & $\mathbf{0 . 5 3}$ & $\mathbf{- 0 . 5 9}$ & $\mathbf{0 . 6 1}$ & - \\
$\mathrm{Si}$ & 0.25 & -0.37 & -0.03 & 0.37 & -0.35 & 0.37 & 0.37 \\
\hline
\end{tabular}




\section{Discussion}

Herbivory damage - The values of leaf area removal found in Q. parviflora are within the range observed for other trees of the Brazilian Cerrado (Fowler \& Duarte 1991, Marquis et al. 2001), and below the mean of $10 \%$ damage found for this same species in a Cerrado in Brasília (Marquis et al. 2001). Nascimento (1989) and Nascimento et al. (1990) found from 2.2\% to $4.6 \%$ damage in Vochysia divergens Pohl (Vochysiaceae), $V$. rufa Mart. (Vochysiaceae) and Curatella americana L. (Dilleniaceae) in an area of Cerrado near Cuiabá, Western Brazil. These authors suggested that the concentration of aluminium in Vochysiaceae and silica in C. americana leaves could influence herbivorous behaviour. However, there is no significant relationship between the concentration of these elements and herbivory in $Q$. parviflora (Gonçalves-Alvim et al. 2006).

According to Fowler \& Duarte (1991), mature leaves in Cerrado do not suffer damage during their whole life, and leaves highly attacked would be aborted. However, in $Q$. parviflora there was an increase of damage in mature leaves, indicating that leaves are attacked by herbivores during their life span (one year), even after they become more sclerophyllous. The increase in herbivore damage on $Q$. parviflora leaves with increasing leaf age corroborates the results of Marquis et al. (2001). These authors found an increase of $2.5 \%$ in damage by herbivores on mature leaves of some plant species in Cerrado between the middle of the rainy season (February) and the end of dry season (August).

Plants in cerrado sensu stricto had the highest damage, while those in cerradão and campo sujo showed lower damage. Similar results were found for galling insects whose abundance was also lower in plants of cerradão (Gonçalves-Alvim et al. unpublished data). Since herbivore insect attacks on Q. parviflora is higher in habitat with soils of intermediate fertility, it is suggested that the indirect effects of soil nutritional status could be stronger than the direct effect of higher vegetation community complexity in cerradão.

Tests of hypotheses on Qualea parviflora defences Qualea parviflora leaves have a mean concentration of tannins and total phenols up to 5.0\%. Velozo (1988) found a higher amount of phenols in $Q$. grandiflora, varying from 8.0 to $14.0 \%$. Bussotti et al. $(1997,1998)$ stated that the accumulation of phenolic compounds in leaves could have an important role in the plant resistance against environmental adversities. In fact, the expression of the genes of PAL (L-phenylanine-ammonia-lyase), the first enzyme in phenolic synthesis, is tightly controlled by developmental stage, cell type, and some environmental factors, such as drought, intense radiation, and attack of microorganisms (Matsuki 1996). Thus, intrinsic traits of Qualea parviflora associated to their environment can be responsible for these differences.

We found higher percentage of tannins and nitrogen in younger than in mature leaves of $Q$. parviflora. The synthesis of phenolic compounds begins in young leaves and some authors reported increases and decreases of tannins and other phenolic metabolites along the leaf development (e.g., Coley 1983a, Mole et al. 1988, Salatino et al. 1993, Velez et al. 1998). Bound to proteins, tannins hinders digestion of plant tissues by blocking the action of digestive enzymes, either binding to proteins being digested or interfering with protein activity in the gut wall (Howe \& Westley 1988). Matsuki (1996) argued that the lower concentration of phenolics in mature leaves could result in the accumulation of other kinds of metabolites in leaves with long life time. Besides, before senescence, leaf material can be recycled for growth of new leaves in expansion (Ferri 1985).

In this study, tannins did not show a significant relationship with herbivory, not corroborating the RAH, but plants of $Q$. parviflora with higher $\mathrm{C} / \mathrm{N}$ ratio have leaves richer in tannins, corroborating the $\mathrm{CNBH}$. Although Q. parviflora is an aluminium-accumulating species, accordding Gonçalves-Alvim et al. (2006), we observed negative correlations between the aluminium and foliar concentrations of $\mathrm{N}$ and other nutrients, such as $\mathrm{K}$ and $\mathrm{P}$. These results suggest that the concentration of leaf tannins can be also affected by the low concentration of nutrients essential to plant growth, as it was observed in other studies (e.g., Coley 1988, Waterman \& Mole 1989, Cornelissen \& Fernandes 2001).

Nitrogen is an important element in the diet of the insects (Mattson 1980), but contrary to expectation, leaves with higher nitrogen concentration were less damaged by herbivorous insects. The nutritional value of plant resources frequently changes seasonally and ontogenically. For example, Filip et al. (1995) found significant reduction in the average values of nitrogen and water as the season progressed, suggesting that for folivorous insects some components of the nutritional quality of the leaves decreased with leaf age. However the relationship between nitrogen and herbivory is still controversial. Moran \& Hamilton (1980) and Furlan et al. (1999) showed that an increase in nitrogen concentration could stimulate leaf damage, while higher survivorship of Phoetaliotes nebrascensis (Orthoptera: Acrididae) was found when it was submitted to a diet 
poor in nitrogen (Joern \& Behmer 1998). However, the pattern obtained in $Q$. parviflora could be explained by the fact that leaf-eating rate by herbivores, in general, is directly proportional to the energy gain by ingestion (Mattson 1980), producing more damage on plants with lower nitrogen content.

Coley (1983b) argued that the absence of correlation between concentration of phenols and leaf herbivory could indicate that young leaves do not show the same defensive mechanisms as mature leaves. As younger leaves were three-fold richer in tannins than mature leaves, this fact could indicate that the leaf age has also an important role in determination of the defensive patterns observed on Q. parviflora in Cerrado. This hypothesis was tested by authors through one study about damage and defensive traits on young leaves of Q. parviflora (Gonçalves-Alvim et al. 2010). Our results suggest that the availability of nutrients to plants in different habitats could be a factor determining production of plant secondary metabolites in $Q$. parviflora. The absence of significant correlation between leaf area damaged and tannin concentration suggests that tannin production is not strongly influenced by herbivore pressure.

Acknowledgements - We thank F. Silveira for field assistance and Dr. John Du Vall Hay for his comments. Financial support was provided by the Sociedade Brasileira de Cultura Japonesa/Fundo Bunka de Pesquisa-Banco Sumitomo, and WWF-USAID (CSR 174-00). We also thank Conselho Nacional de Desenvolvimento Científico e TecnológicoCNPq (479684/2001-4), Fapemig (CRA 388101) and US Fish and Wildlife Service. The CNPq provided a scholarship to S. J. GA. The logistical support was provided by Ecological Station of Pirapitinga and Instituto Brasileiro de Recursos Renováveis e Meio Ambiente. We are also grateful to Empresa Brasileira de Pesquisa Agropecuária for plant analyses.

\section{References}

ALLAIN, L.R., LARA, A.C.F., FERNANDES, G.W. \& MARQUES, E.S.A. 1998. Leaf tannin concentration, toughness, and sclerophylly in some typical woody species of the savannas of southeastern Brazil. Bios 6:5-10.

AZEVEDO, L.G., BARBOSA, A.A., OLIVEIRA, A.L., GORGONIO, A.S., BEDRETCHUCK, A.C., SIQUEIRA, F.B., RIZZO, H.G., SILVA, I.S., MOURA, L.C., MILTON FILHO, A. \& SANTOS, R.V. 1987. Ensaio metodológico de identificação e avaliação de unidades ambientais: a estação Ecológica de Pirapitinga, MG. SEMA/Empraba-CPAC/MDU, Brasília.

BARROSO, G.M. 1991. Sistemática de Angiospermas do Brasil. Universidade Federal de Viçosa, Viçosa, v.2.
BERNAYS, E.E., DRIVER, G.C. \& BILGENER, M. 1989. Herbivores and plant tannins. Advances in Ecological Research 19:263-303.

BRYANT, J.P., CHAPIN, F.S. \& KLEIN, D.R. 1983. Carbon/ nutrient balance of boreal plants in relation to vertebrate herbivory. Oikos 40:357-368.

BUSSOTI, F., GROSSONI, P. \& BOTTACCI, A. 1997. Sclerophylly in beech (Fagus sylvatica L.) trees: its relationship with crown transparency, nutritional status and summer drought. Forestry 70:267-271.

BUSSOTI, F., GRAVANO, E., GROSSONI, P. \& TANI, C. 1998. Occurrence of tannins in leaves of beech trees (Fagus sylvatica) along an ecological gradient, detected by hystochemical and ultraestrutural analyses. New Phytologist 138:469-479.

CARLSON, R.M., CABRERA, R.I., PAUL, J.L., QUICK, J. \& EVANS, R.Y. 1990. Rapid direct determination of ammonium and nitrate in soil and plant tissue extracts. Communication on Soil Science and Plant Analyses 21:1519-1529.

COLEY, P.D. 1983a. Intraspecific variation in herbivory on two tropical tree species. Ecology 64:426-433.

COLEY, P.D. 1983b. Herbivory and defensive characteristics of tree species in a lowland tropical forest. Ecological Monographs 53:209-233.

COLEY, P.D. 1988. Effects of plant growth rate and leaf lifetime on the amount and type of anti-herbivore defense. Oecologia 74:531-536.

COLEY, P.D., BRYANT, J.P. \& CHAPIN, F.S. 1985. Resource availability and plant antiherbivore defense. Science 230:895-899.

CORNELISSEN, T. \& FERNANDES, G.W. 2001. Defense, growth, and nutrient allocation in the tropical shrub Bauhinia brevipes (Leguminosae). Austral Ecology 26:246-253.

ELLIOTT, C.L. \& SNYDER, G.H. 1991. Autoclave-induced digestion for the colorimetric determination of silicon in rice straw. Journal of Agricultural Food and Chemistry 39:1118-1119.

ERNEST, K.A. 1989. Insect herbivory on a tropical understory tree: effects of leaf age and habitat. Biotropica 21:194199.

EITEN, G. 1972. The cerrado vegetation of Brazil. Botanical Review 38:201-341.

EITEN, G. 1993. Vegetação de cerrado. In Cerrado: caracterização, ocupação e perspectivas (M. N. Pinto, ed.). Editora da Universidade de Brasília, Brasília, p.17-73.

FELIPPE, G.M. \& DALE, J.E. 1990. The effects of phosphate supply on growth of plants of the Brazilian Cerrado: experiments with seedlings of the annual weed, Bidens gardneri Baker (Compositae) and the tree, Qualea grandiflora (Mart.) (Vochysiaceae). Oecologia 82:81-86.

FERRI, M.G. 1985. Fisiologia vegetal. EPU, São Paulo, v.2. 
FILLIP, V., DIRZO, R., MAASS, J.M. \& SARUKHÁN, J. 1995. Within- and among year variation in the levels of herbivory on the foliage of trees from Mexican tropical deciduous forest. Biotropica 27:78-86.

FOWLER, H.G. \& DUARTE, L.C. 1991. Herbivore pressure in a Brazilian cerrado. Naturalia 16:99-102.

FURLAN, C.M., SALATINO, A. \& DOMINGOS, M. 1999. Leaf content of nitrogen and phenolic compounds and their bearing with the herbivory damage to Tibouchina pulchra Cogn. (Melastomataceae), under the influence of air pollutants from industries of Cubatão, São Paulo. Revista Brasileira de Botânica 22:317-323.

FURLEY, P.A. 1999. The nature and diversity of Neotropical savanna vegetation with particular reference to the Brazilian cerrados. Global Ecology and Biogeography Letters 8:223-241.

GOODLAND, R. \& FERRI, M.G. 1979. Ecologia do cerrado. Universidade de São Paulo, Itatiaia, São Paulo.

GONÇALVES-ALVIM, S.J. \& FERNANDES, G.W. 2001. Biodiversity of galling insects: historical, community and habitat effects in four Neotropical savannas. Biodiversity and Conservation 10:79-98.

GONÇALVES-ALVIM, S.J., KORNDORF, G. \& FERNANDES, G.W. 2006. Sclerophylly in Qualea parviflora (Vochysiaceae): influence of herbivory, mineral nutrients, and water status. Plant Ecology 187:153-162.

GONÇALVES-ALVIM, S.J., LANA, T., RANIERI, B., SILVEIRA, F.A.O., RIBEIRO, W. \& FERNANDES, G.W. 2010. Growth, defense and herbivory on young leaves of Qualea parviflora (Vochysiaceae) in three different Cerrado habitats. Neotropical Biology and Conservation 5:86-92.

HAGERMAN, A.E. 1987. Radial diffusion method for determining tannin in plant extracts. Journal of Chemical Ecology 13:437-449.

HAGERMAN, A.E. \& BUTLER, L.G. 1991. Tannins and lignins. In Herbivore: their interactions with secondary plant metabolites (G.A. Rosenthal \& M.R. Beranbaum, eds.). Academic Press, London, v.1, p.355-388.

HARIDASAN, M. 1982. Aluminum accumulation by some cerrado native species of central Brazil. Plant and Soil $65: 265-273$.

HOWE, H.F. \& WESTLEY, L.C. 1988. Ecological relationships of plants and animals. Oxford University Press, New York.

JANZEN, D.H. \& SCHOENER, T.W. 1968. Differences in insect abundance and diversity between wetter and drier sites during tropical season. Ecology 49:96-110.

JANZEN, D.H. 1973. Sweep samples of tropical foliage insects: effects of season, vegetation types, elevation, time of day, and insularity. Ecology 54:687-708.

JANZEN, D.H. 1981. Patterns of herbivory in a tropical deciduous forest. Biotropica 13:271-281.

JOERN, A. \& BEHMER, S.T. 1998. Impact of diet on quality on demographic attributes in adult grasshoppers and the nitrogen limitation hypothesis. Ecological Entomology 23:174-184.
KÖPPEN, W. 1931. Klimakarte der Erde. Grundriss der Klimakunde, 2nd ed., Berlin and Leipzig.

LOPES, A.S. \& COX, F.R. 1977. Cerrado vegetation in Brazil: an edaphic gradient. Agronomy Journal 69:828-831.

LORENZI, H. 2000. Árvores brasileiras: manual de identificação e cultivo de plantas arbóreas nativas do Brasil. Instituto Plantarum, Nova Odessa, v.1.

MARQUIS, R.J., DINIZ, I.R. \& MORAIS, H.C. 2001. Patterns and correlates of interspecific variation in foliar insect herbivory and pathogen attack in Brazilian cerrado. Journal of Tropical Ecology 17:127-148.

MATSUKI, M. 1996. Regulation of plant phenolic synthesis: from biochemistry to ecology and evolution. Australian Journal of Botany 44:613-634.

MATTSON, W.J. 1980. Herbivory in relation to plant nitrogen content. Annual Review of Ecology and Systematics 11:119-161.

MEYER, G.A. \& KELIHER, P.N. 1992. An overview of analysis by inductively coupled plasma-atomic emission spectrometry. In Inductively coupled plasmas in analytical atomic spectrometry (A. Montaser \& D.W. Golightly, eds.). VCH Publishers, New York, p.473-505.

MOLE, S., ROSS, J.A.M. \& WATERMAN, P.G. 1988. Lightinduced variation in phenolic levels in foliage of rainforest plants. I. Chemical changes. Journal of Chemical Ecology 14:1-21.

MOLES, A.T. \& WESTOBY, M. 2000. Do small leaves expand faster than large leaves, and do shorter expansion times reduce herbivory? Oikos 90:517-524.

MORAIS, H.C., DINIZ, I.R. \& BAUMGARTEN, L. 1995. Padrão de produção de folhas e sua utilização por larvas de Lepidoptera em um cerrado em Brasília. Revista Brasileira de Botânica 18:163-170.

MORAN, N. \& HAMILTON, W.D. 1980. Low nutritive quality as defence against herbivores. Journal of Theoretical Biology 86:247-254.

NASCIMENTO, M.T. 1989. Herbivoria foliar em Vochysia divergens Pohl. Brasil Florestal 68:51-54.

NASCIMENTO, M.T., VILLELA, D.M. \& LACERDA, L.D. 1990. Foliar growth, longevity and herbivory in two "cerrado" species near Cuiabá, MT, Brazil. Revista Brasileira de Botânica 13:27-32.

OLIVEIRA, P.E. \& GIBBS, P.E. 2000. Reproductive biology of woody species in a cerrado community in Central Brazil. Flora 195:311-329.

RIBEIRO, S.P. \& FERNANDES, G.W. 2000. Interações entre insetos e plantas no cerrado: teoria e hipóteses de trabalho. In Ecologia e comportamento de insetos (R.P. Martins, T. Lewinsohn, M. \& M.S. Barbeitos, eds.). Série Oecologia Brasiliensis, Universidade Federal do Rio de Janeiro, Rio de janeiro, v.3, p.299-320.

SALATINO, A., KRAUS, J.E. \& SALATINO, M.F.L. 1993. Contents of tannins and their histological localization in young and adult parts of Struthanthus vulgaris Mart. (Loranthaceae). Annals of Botany 72:409-414. 
SCHOONHOVEN, L.M., JERMY, T. \& VON LOON, J.J.A. 1998. Insect-plant biology: from physiology to evolution. Chapman Hall, London.

SCHULTZ, J.C., NOTHNAGLE, P.J. \& BALDWIN, I.T. 1982. Seasonal and individual variation in leaf quality of two Northern hardwood tree species. American Journal of Botany 69:753-759.

SCION-IMAGE Software. 1998. Scion Corporate. Freely available in http://www.scioncorp.com/

SWAIN, T. 1979. Tannins and lignins. In Herbivores: their interactions with secondary plant metabolites (G.A. Rosenthal \& D.H. Janzen, eds.). Academic Press, New York, p.657-682.

TUOMI, J., NIEMELÄ, P., CHAPIN, F.S., BRYANT, J.P., \& SIRÉN, S. 1988. Defensive responses of trees in relation to their carbon/nutrient balance. In Mechanisms of woody plant defences against insects: Search for pattern (W.J. Mattson, J. Levieux, \& C. Bernard-Dagan, eds.). Springer-Verlag, New York, p.57-72.

VÉLEZ, V., CAVELIER, J. \& DEVIA D.B. 1998. Ecological traits of the tropical treeline species Polylepis quadrijuga (Rosaceae) in the Andes of Colombia. Journal of Tropical Ecology 15:771-787.
VELOZO, E.S. 1988. Variabilidade de algumas classes de metabólicos secundários em folhas coletadas em três regiões do estado de São Paulo. Dissertação de mestrado, Universidade de São Paulo, São Paulo.

WALKELY, A. \& BLACK, I.A. 1934. An examination of Degtjareff method for determining soil organic matter and a proposed modification of the cromic acid titration method. Soil Science 37:29-37.

WATERMAN, P.G. \& MOLE, S. 1989. Extrinsic factors influencing production of secondary metabolites in plants. In Insect-plant interactions (E.A Bernays, ed.). CRC Press, Boca Raton, p.107134.

WHITTAKER, R.K. \& FEENY, P.P. 1971. Allelochemics: chemical interactions between species. Science 171:757769 .

WITKOSWSKI, E.T.F. \& LAMONT, B.B. 1991. Leaf specific mass confounds leaf density and thickness. Oecologia 88:486-493.

WOLDA, H. 1978. Seasonal fluctuations in rainfall, food and abundance of tropical insects. Journal of Animal Ecology 47:369-381.

ZAR, J.H. 1996. Biostatistical analysis. Prentice Hall, New Jersey. 